\title{
SOCIALNOGEOGRAFSKA ZGRADBA SLOVENSKIH MEST NA KVALITETNEM PREHODU
}

\author{
Mirko Pak*
}

Izvleček

UDK $911 \cdot 375.64$ (497.12)

Na primerih nekaterih elementov socialne zgradbe Ljubljane, Maribora, Kranja in Velenja je prikazan najnovejši razvoj socialnogeografske zgradbe, ki je zajel vsa slovenska mesta.

Ključne besede: urbana geografija, socialna struktura, prebivalstvo, Ljubljana, Maribor, Kranj, Velenje.

\section{SOCIOGEOGRAPHICAL STRUCTURE OF SLOVENIAN TOWNS IN QUALITATIVE TRANSITION}

Abstract

UDC $911 \cdot 375.64$ (497.12)

By exposing certain elements of social structure in Ljubljana, Maribor, Kranj and Velenje, the most recent development of the socio-geographical structure is presented, which has started in all Slovenian towns.

Key words: Urban geography, Social structure, Population, Ljubljana, Maribor, Kranj, Velenje

\section{UVOD}

Kolikor soglašamo, da se socialna geografija ukvarja s prostorsko organizacijo in s prostorsko relevantnimi procesi, ki izhajajo iz osnovnih človekovih funkcij (Schaffer, 1968), potem je jasno, da so naselja, še posebej urbana, vrh tovrstnega zanimanja. Družbene strukture v prostorskem sistemu funkcij in procesov so tiste, ki sestavljajo mestno zgradbo in usmerjajo njen razvoj. Nesporno je $v$ osredju te zgradbe prebivalstvo $\mathrm{z}$ vsemi svojimi socialnimi in prostorskimi značilnostmi in vedno večjo dinamiko. Glede na to govorimo o "akcijskem prostoru", opredeljenem z določeno vrsto vpliva, ki je vedno rezultat sistema vplivanja večih elementov in dejavnikov. Zato vlada med bivanjem, akcijskim prostorom in zgradbo mesta tesna dinamična in funkcionalna povezava, (Horton, Reynolds, 1971).

Pred leti izpostavljeno zanimanje geografov za socialne elemente in socialno zgradbo mest, zlasti Srednje Evrope, ter ponovno oživljena problematika segregacije v anglo-

\footnotetext{
*Dr., prof., Oddelek za geografijo, Filozofska fakulteta Univerze v Ljubljani, Aškerčeva 2, 61000 Ljubljana, Slovenija
} 
saških preučevanjih postaja vse bolj kompleksno. To pa pomeni vključevanje novih socialnogeografskih elementov zgradbe mest $v$ geografska proučevanja.

Schaffer je veliko pisal o socialnih skupinah kot nosilcih prostorskega razvoja $v$ smislu njihovega gospodarskega potenciala in s tem povezanim načinom življenja (Schaffer, 1971). Bolj sintetske raziskave, zlasti ameriških geografov, pa vključujejo niz alternativnih kriterijev za človekov "well-being" (Herbert, Smith, 1979). Vendar je praksa pokazala, da tudi podrobnejše poznavanje posameznih socialnih elementov mesta omogoča njegovo razumevanje in razlago struktur ter procesov $\mathrm{v}$ mestnem razvoju.

Socialnogeografska zgradba je na splošno sila občutljiva, spremenljiva in vitalna. Reagira že na najmanjše spremembe $v$ strukturi in vrednosti mestnega prostora ter je pravzaprav $\mathrm{v}$ tem pogledu ekonomska kategorija, $\mathrm{v}$ harmoniji $\mathrm{z}$ drugimi zgradbenimi elementi naselij in posebej mest. V bolj razvitem okolju je vitalnost seveda večja. Glede na tržne zakonitosti, ki stopajo v ospredje tudi pri nas, se to vedno pogosteje dogaja tudi $v$ naših mestih. En segment so nedvomno profitne najemnine $z$ vsemi posledicami v socialni, pa tudi funkcijski zgradbi naših mest.

Součinkovanje elementov in dejavnikov mestne zgradbe, temelječih na socialni osnovi je Schaffer prikazal v kratkem članku "Die Sozialgeographie des Aktionsraumes" (Schaffer, 1985).

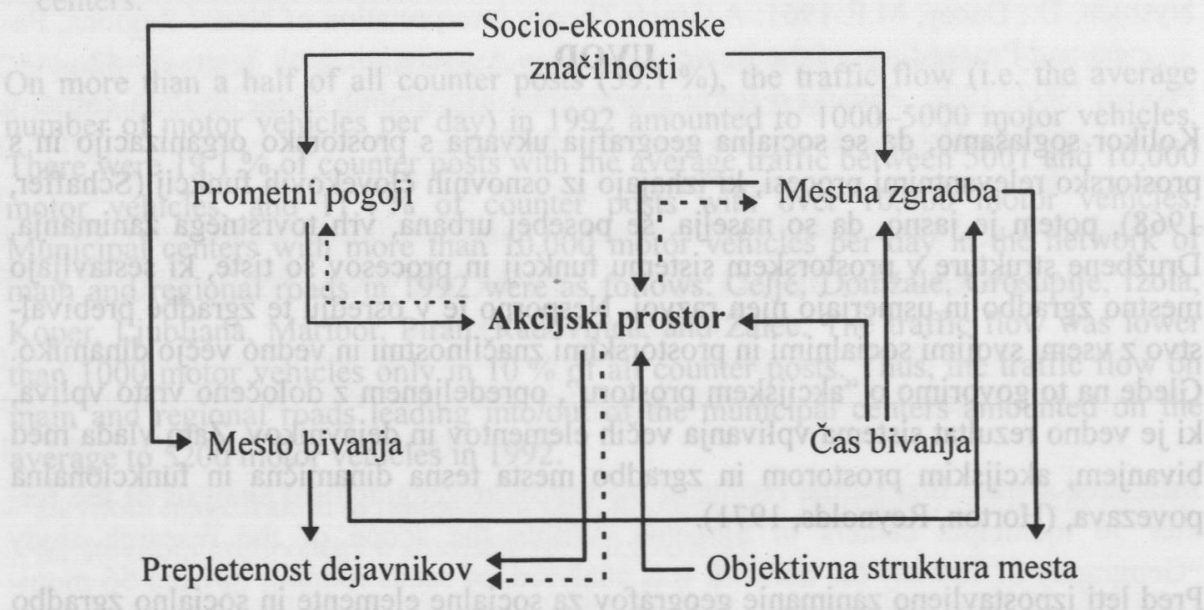

Akcijski prostor predstavlja $\mathrm{v}$ bistvu regionalno sintezo, ki jo Wolf $\mathrm{v}$ kontekstu regionalne geografije opredeljuje kot reagiranje človeka $\mathrm{v}$ njegovem odnosu do regionalnega ekološkega stanja, oziroma celotnega življenjskega okolja (Wolf, 1994). 
$\mathrm{Z}$ izpostavljanjem človeka kot izvora in nosilca vseh regionalnih sprememb (tudi $\mathrm{v}$ urbanem prostoru), pravzaprav utemeljuje bolj procesno-sintetsko-problemsko socialnogeografsko analizo. Ta pa še posebej velja za nadvse dinamični, visoko vredni urbani prostor.

\section{IZBRANI ELEMENTI V SOCIALNI ZGRADBI NEKATERIH SLOVENSKIH MEST}

Medtem ko živahnejše spremembe $v$ ekonomsko močnejših mestih razvitih evropskih držav zajemajo predvsem določene predele, doživljajo naša mesta močnejše spremembe praktično $\mathrm{v}$ vseh svojih strukturah $\mathrm{v}$ smislu spreminjanja vrednosti stanovanjskih in nestanovanjskih predelov. Nasploh se je vrednost osrednjih mestnih predelov povečala, kar hitro spreminja socialno sestavo prebivalstva in samo rabo prostora. To ne izrinja stanovanjske funkcije le iz mestnih središč, temveč tudi iz njihovih obrobij. Tovrstne nagle spremembe doživljajo tudi glavne ceste, ki mesta povezujejo z okolico. Ob tem se krepijo in širijo poslovni, poslovno-oskrbni in oskrbni predeli ter ulice. K temu prispeva precejšen delež še denacionalizacija.

Sicer so še vedno redke študije socialne zgradbe naših mest pokazale na kompaktnost tega zgradbenega elementa, na visoko prisotnost podedovanih struktur predvsem iz industrijskega obdobja njihovega razvoja in na visoko soodvisnost $\mathrm{z}$ morfološko in funkcijsko zgradbo. Nekaj naslednjih primerov novejših preučitev posameznih socialnostrukturnih elementov $v$ naših mestih naj bi zgornja izhodišča dokumentiralo.

Za socialnogeografsko zgradbo Ljubljane, ki je zavoljo svoje vodilne funkcije doživljala najmočnejše in najpestrejše spremembe, je $\mathrm{v}$ osnovi značilna dvojna zasnova: radialna $\mathrm{v}$ odnosu do mestnega središča in modificirana $\mathrm{z}$ osnovnimi prometnicami, ob katerih so se razvijala središča bivših ljubljanskih občin.

Glede na to sta se oblikovala tudi gostota in nacionalna sestava prebivalstva. Gostota prebivalstva, ki se $v$ središču Ljubljane že desetletja zmanjšuje predvsem zaradi spremembe rabe prostora in $\mathrm{v}$ vedno manjši meri zaradi neugodnega naravnega prirastka, se je povečala le $\mathrm{v}$ predelih novogradenj, praviloma na mestnem obrobju. In ker je zlasti po letu 1980 novogradenj vedno manj, še posebej blokovskih naselij, je začelo prebivalstvo, ob splošni počasnejši rasti, nazadovati tudi izven tradicionalno depresivnega središča.

Ob povprečni gostoti 19 ljudi na ha leta 1991 , je podpovprečno gostoto imelo 41 statističnih okolišev ( $\mathrm{v}$ nadaljevanju predelov), nadpovprečno pa 59 , od tega 22 med 50 in 100 ter le 10 nad 100 prebivalcev na ha. In ker med slednje sodijo le predeli z obsežnejšimi novogradnjami, primerjava z letom 1971 pa kaže povečano heterogenost in depresijo središčnih predelov, je za samo središče in njegovo obrobje značilno sta- 
ranje prebivalstva (Pak, 1993). In ker je podobno v nekaterih predelih starejših blokov, je tak proces že zajel obsežen sklenjen mestni teritorij. S tem pa postaja starostna sestava prebivalstva prevladujoč dejavnik socialne zgradbe in trendov njenega razvoja.

Druga analiza, ki postavlja $\mathrm{v}$ ospredje prostorsko analizo narodnostne, pa tudi izobrazbene in dejavnostne sestave prebivalstva, kaže predvsem na dva pojava: na velike spremembe $\mathrm{v}$ dvajsetletnem obdobju in na močno prostorsko heterogenizacijo (Pak, 1993). Leta 1971 je bilo neslovensko prebivalstvo v mestu dokaj enakomerno razporejeno, njihov delež nad $10 \%$ pa se je vezal na ekološko manj primerne lokacije, zlasti na južnem obrobju mesta in v industrijskih Mostah. Danes je to postal središčno-periferni model s tem, da imajo nad $20 \%$ neslovenskega prebivalstva poleg nekaterih predelov $\mathrm{v}$ ožjem središču, zlasti novejši blokovski predeli iz obdobja gradnje solidarnostnih stanovanj in nekateri robni predeli enodružinskih hiš, zgrajenih na naravno in sploh ekološko slabših lokacijah. Da so ti predeli v pozitivni korelaciji z nižjo kvaliteto bivalnega okolja, ni treba posebej poudarjati (graf 1). Podrobnejša analiza za leto 1991 pa ob vsej heterogenosti, ki je v Ljubljani mnogo večja kot v ostalih slovenskih mestih, kaže na precejšnje prostorske povezave med narodnostno, izobrazbeno ter dejavnostno sestavo prebivalstva.

Graf 1: Ljubljana — delež Slovencev.

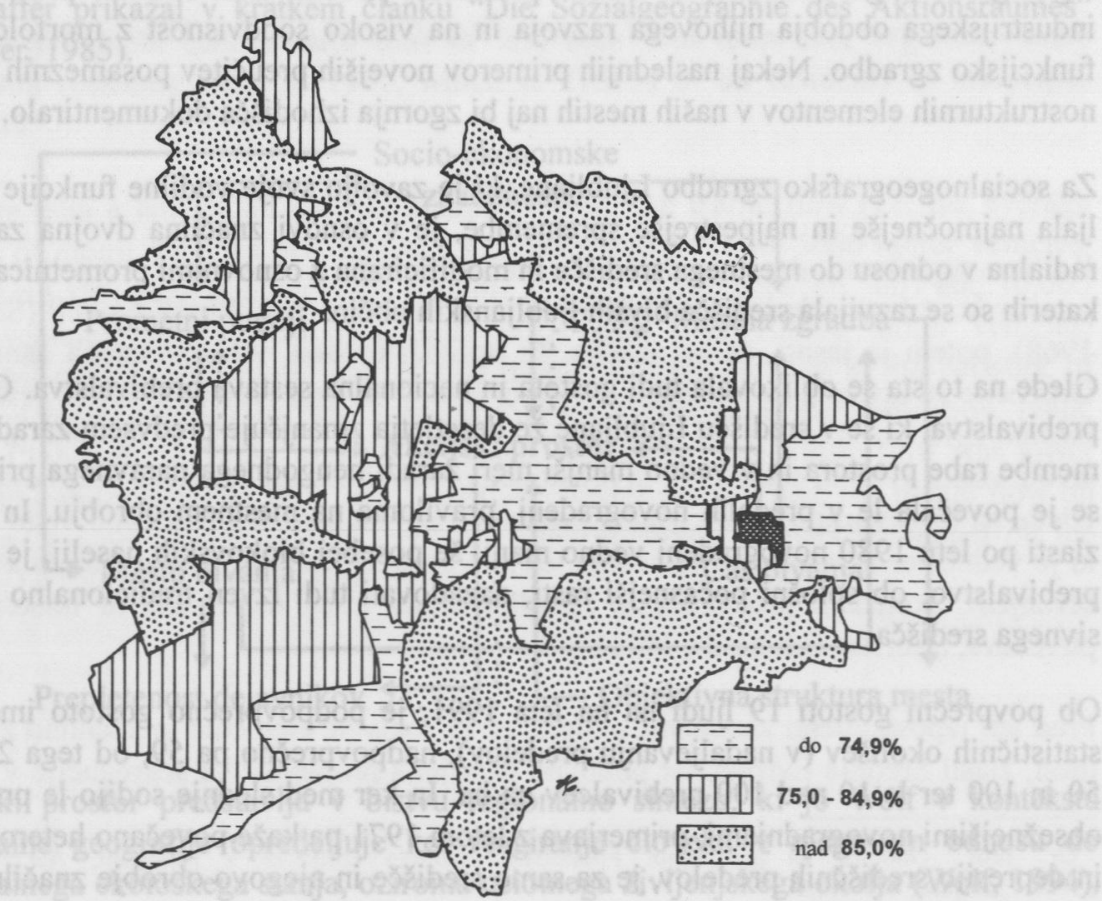


Tudi raziskave nekaterih socialnogeografskih elementov $v$ zgradbi Maribora so pokazale novejše razvojne zakonitosti, ki močno odstopajo od tistih iz časa industrializacije po drugi svetovni vojni, pa tudi od zadnjih let. Žal tega ni mogoče primerjati z Drozgovo karto kvalitete bivalnega okolja, ker na njej ni vidna razlika med predeli z zadovoljivo in neprimerno kvaliteto, ki obsegajo veliko večino mestnega teritorija (Drozg, 1994).

Zaradi poglobljenih gospodarsko-razvojnih problemov je v Mariboru skupaj z njegovim obrobjem razvoj prebivalstva prešel $v$ fazo stagnacije. Takšen proces je zajel praktično ves mestni teritorij, na katerem je v obdobju 1971-91 kar $64 \%$ vseh statističnih okolišev beležilo zmanjšanje števila prebivalstva. Ker se to nazadovanje in širjenje poglablja, lahko predvidevamo še za nekaj časa podoben razvoj.

Nekdaj na socialno homogene predele zdiferenciran mestni prostor, je predvsem po letu 1970 postajal zaradi živahne urbanizacije obrobja mestnega središča vedno bolj heterogen. Posledica tega je dokajšnje prepletanje socialne zgradbe, ki se je kazala že $\mathrm{v}$ sedemdesetih letih. Še vedno pa daje osnovni pečat mestni zgradbi osnovni model z višjo socialno strukturo na levem bregu Drave ter z nižjo, predvsem industrijsko, na območju starih industrijskih predelov Melje, Tezno, Studenci, del Tabora in na Pobrežju (Pak, 1991).

Glede na to $v$ obdobju 1971-91 ni več sklenjenih socialno enotnih predelov s podobnim razvojem prebivalstva, temveč je ves mestni teritorij močno heterogen. Višji porast števila prebivalstva tudi ni več odvisen od nižje ali delavske strukture, temveč od starostne sestave prebivalstva. Ta pa je ob prebivalstveno izrazito starem središču postala vedno bolj neugodna tudi $\mathrm{v}$ drugih socialno manj ugodnih, predvsem "delavskih predelih", še posebej pa v samih industrijskih predelih. Rast prebivalstva je značilna le za nova stanovanjska območja.

Znotraj dvajsetletnega obdobja 1971-91 so velike razlike med obema desetletjema (1971-81 in 1981-91). V zadnjih desetih letih se je območje $\mathrm{z}$ rastjo in še posebej s hitrejšo rastjo prebivalstva močno skrčilo na predele novejše gradnje. Neugoden prebivalstveni razvoj pa je zajel že tudi vrsto predelov novejše pozidave (Pak, 1991a), (graf 2, 3, 4).

Pozidava prostih površin v mestnem središču, značilna za razvoj Maribora v osemdesetih letih (Lent in drugo), je nekaterim središčnim predelom prinesla ugodnejši prebivalstveni razvoj. Vrsta zlasti ekonomskih in ekoloških dejavnikov, ki so povečali privlačnost bivanja $v$ mestnem središču in $v$ mestu nasploh, pa so $v$ Mariboru še posebej močno vplivali na izboljšanje središčnih predelov na levem bregu Drave in predelov enodružinskih hiš na obrobju središča Tabora, kar se je takoj poznalo v ugodnejšem gibanju števila prebivalstva (Pak, 1994). 


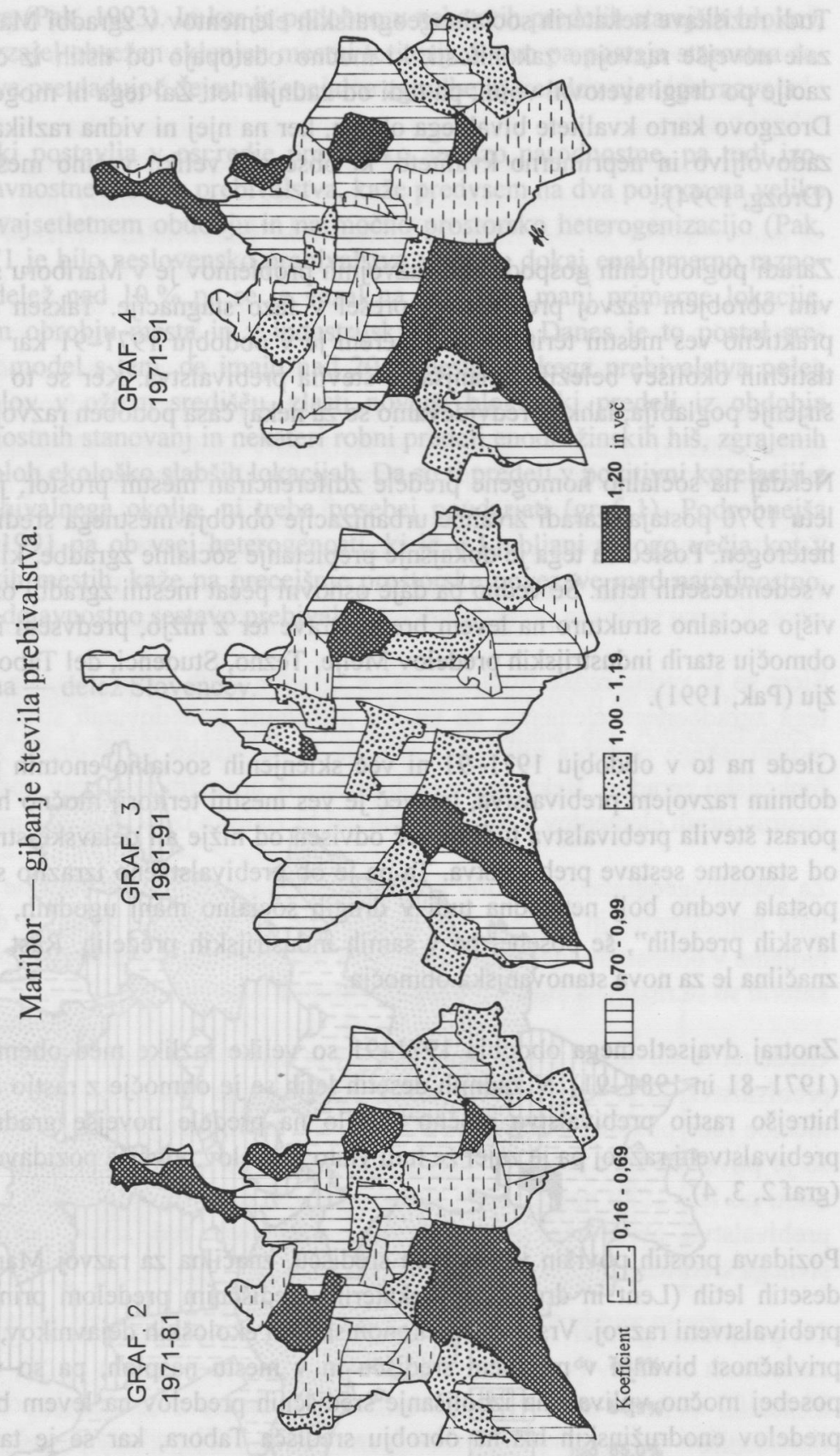


Zaradi manjšega teritorija nekoliko poenostavljene, vendar podobne trende prostorskega razvoja, beleži kranjsko prebivalstvo, kjer je socialna struktura še bolj neposreden rezultat dokaj ostro ločene gospodarske zgradbe mesta. Blokovna gradnja je vedno pomenila tudi visoko gostoto prebivalstva, ki se je pomikala na vzhodno obrobje mesta. Več kot tretjina prebivalstva ureditvenega območja živi v soseskah Planina I, II in III na območju Planine in Primskovega. Samo še v območjih novejše stanovanjske gradnje Drulovka, Stražišče in Čirče beležijo v zadnjih letih nadpovprečno rast in tudi ugodnejšo starostno sestavo prebivalstva.

V obdobju 1981-91 se je prebivalstvo Primskovega pomnožilo za $68,2 \%$, Planine za $38,0 \%$, Orehka-Drulovke za $28,9 \%$, Čirč za $4,9 \%$ in Stražišča za $2,7 \%$. Drugod se je število prebivalstva zmanjšalo, najmočneje $v$ mestnem središču. Poleg razvoja terciarja je temu kriv neugoden naravni prirastek in negativni migracijski saldo, zaradi česar se prebivalstvo hitro stara. Podoben razvoj traja že od začetka sedemdesetih let, še posebej $v$ redkeje poseljenih, obrobnih in industrijskih predelih.

Nova blokovna naselja so pritegnila veliko mladega nizkokvalificiranega prebivalstva iz mestnega središča in iz okolice, zaradi česar se je razlika $\mathrm{v}$ socialni sestavi prebivalstva mestnih predelov močno povečala (Pak, 1995).

Zaradi svojega mladega razvoja kaže še posebno zanimivo socialnogeografsko zgradbo Velenje. V naselje s 30.287 prebivalci se je večina prebivalstva priselila iz okoliških naselij, zaradi pomanjkanja domače delovne sile pa tudi veliko iz drugih republik bivše Jugoslavije. Neslovencev je bilo leta 1991 kar 21,2\%, delež mladega, do 14 let starega prebivalstva kar $25 \%$, nad 60 let starega pa $9,9 \%$.

Socialna zgradba Velenja je izrazito povezana s kvaliteto bivalnega okolja, odvisnega od starosti in od vrst pozidave. Zato ima najmanj ugodno socialno sestavo predel najstarejših blokov severno od Pake, z visokim deležem starega prebivalstva, slabšo kvalifikacijsko sestavo in visokim deležem neslovenskega prebivalstva. Temu sledi ožje mestno središče s posebej visokim deležem neslovenskega in starega prebivalstva. Najbolj ugodno socialno zgradbo pa je vezana na nove predele enodružinskih hiš in blokov na vzhodnem obrobju naselja.

\section{SKLEP}

Socialna zgradba slovenskih mest je na splošno močno odvisna od ekoloških pogojev, oziroma od kvalitete bivalnega okolja, ki je vsaj v večini slovenskih mest opredeljena $\mathrm{z}$ njihovo industrijsko funkcijo, ob tem pa $\mathrm{z}$ industrijskimi ter delavskimi predeli. Glede na to in na časovni razvoj je povsod močno prisoten radialni model socialne zgradbe. Opazna je prostorska trojnost v socialno-zgradbenem razvoju mestnih središč: 
stanovanjsko funkcijo izgubljajo tudi širša mestna središča zaradi prevlade starega prebivalstva, kar v prvi vrsti vpliva na naravni prirastek prebivalstva; neugoden razvoj je tudi na obrobju mestnih središč in le obrobja mest $\mathrm{z}$ močnejšo novejšo urbanizacijo doživljajo ugoden prebivalstveni razvoj.

Novejši razvoj je dokaj homogeno socialno zgradbo mest močno razrahljal, še posebej $v$ ožjem pomenu socialne zgradbe, to je $v$ ekonomskih obeležjih, ki so jim blizu zlasti starostna sestava in s tem povezana reprodukcijska sposobnost prebivalstva. Tako je ugodnejši prebivalstveni razvoj $v$ naših mestih vezan izključno le na najnovejšo urbanizacijo.

$\mathrm{V}$ ospredje stopa revitalizacija mestnih središč, ki vodi $\mathrm{v}$ vzpostavljanje ugodnejše strukture in ugodnejši prebivalstveni razvoj, zlasti v ekološko boljših predelih.

V bistvu gre za korenite spremembe $\mathrm{v}$ socialni zgradbi naših mest, ki močno spreminjajo dosedanje stanje, kar prav $\mathrm{v}$ tem obdobju zahteva poglobljeno raziskovanje.

\section{LITERATURA}

Drozg, V. 1994: Kvaliteta bivalnega okolja v stanovanjskih območjih v Mariboru. Trajnostni urbani razvoj, str. 105-115. Maribor.

Herbert, T.D.; Smith, H.D. 1979: Social Problems, the City. Geographical Perspectives. Oxford.

Horton, F.E.; Reynolds, D.R. 1971: Effects of urban spatial structure on individual behaviour. Economic Geography 47, str. 36-48.

Pak, M. 1991: Socialnogeografska problematika "delavskih" predelov v zgradbi industrijskih središč, na primeru Maribora. ČZN, letnik 92, 1, str. 15-24. Maribor.

Pak, M. 1991a: Nekateri elementi razvoja prebivalstva Maribora. Geografski vestnik 63, str. 81-96. Ljubljana.

Pak, M. 1993: Geografska problematika narodnostne sestave prebivalstva v Ljubljani. Geographica Slovenica 24, str. 51-63. Ljubljana.

Pak, M. 1994: Razvoj in struktura prebivalstva. Maribor - Marburg. str. 57-77. Maribor.

Pak, M. 1995: Nekateri geografski elementi zgradbe Kranja. Kranjski zbornik 1995. Kranj (v tisku).

Schaffer, F. 1971: Prozesstypen als sozialgeographisches Gliederungsprinzip. Mitteilungen der Geographischen Gesellschaft in Munchen, 1971, str. 33-52. München.

Schaffer, F. 1985: Die Sozialgeographie des Aktionsraumes. Angewandte Sozialgeographie 11, Universitat Augsburg.

Wolf K. 1994: Die gesellschaftliche Auftrag der geographischen Landerkunde. Berichte zur deutschen Landeskunde 68, H 2, str. 361-367. Trier. 


\section{SOCIOGEOGRAPHICAL STRUCTURE OF SLOVENIAN TOWNS IN QUALITATIVE TRANSITION}

\section{Summary}

Since the beginning of the eighties, Slovenian towns have been in transition. It has been manifested in several ways: from the social aspect, the interest has increased in residing in towns and their centers, and, consequently, the trend of impairment in the social structure has shifted to the trend of improvement; from the functional aspect, in the development of $\mathrm{CBD}$; from the morphological-building aspect, in re-constructions of old and constructions of new buildings have been accellerated, built-up areas have become denser; from the economic aspect, the prices and the rents of space have risen. The rising of the value of urban space is, simultaneously, the cause and the result, and furthermore, it is the basic factor of the re-evaluation and transformation of urban space. The development of $\mathrm{CBD}$ and the processes of differentiation, modernization and "segregation" in the sense of social differentiation, which were all relatively slow in the eighties, have recently got full swing.

In general, the social structure of Slovenian towns heavily depends on ecological conditions or the quality of dwelling environment which is marked in the majority of Slovenian towns by their industrial function and industrial and workers' districts. Spatial triplicity can be observed in the socio-structural development of city centers: the residential function is being lost; population is heavily declining also in the wider centers due to the prevailing aged population which, in the first place, affects natural increase of the population; the unfavourable trend of development is also spreading to the edges of city centers, and it is only the suburban areas with more intense recent urbanization that are undergoing more favourable population development.

The recent development has heavily shattered the relatively homogeneous social structure of towns, the social structure in the narrower sense in particular, that is its economic characteristics which are closely connected with the age structure and the related reproduction capacity of the population. Thus, a more favourable population development in our towns is strictly connected with recent urbanization only. Parallel to it, revitalization of town cores is becoming ever more important, because it leads to the establishment of a more favourable structure and a more favourable population development particularly in the districts of higher ecological quality. 